Jurnal Agroteknologi, Vol. 10 No. 1, Agustus $2019: 33-40$

\title{
REVIEW: PEMANFAATAN BROMELIN PADA BEBERAPA PANGAN LOKAL INDONESIA
}

\author{
(Review: Utilization of Bromelain on Several Indonesian Local Foods) \\ WARSONO EL KIYAT ${ }^{1 *}$, KEVIN REYNALDO², JEREMIAH IRWAN² \\ ${ }^{1}$ Institute of Biochemical Science, College of Life Sciences, National Taiwan University \\ No.1, Section 4, Roosevelt Rd, Da'an District, Taipe City 10617, Taiwan \\ ${ }^{2}$ Departemen Teknologi Pangan, Fakultas IImu Hayati, Universitas Surya, \\ JI. MH. Thamrin KM 2.7, Banten 15117, Indonesia \\ *Email: warsono.el.kiyat@gmail.com HP : 087711052329
}

\begin{abstract}
Bromelain is one of the protease that can be produced from all parts of the pineapple plants (Ananas comosus). It has potential to improve quality of local Indonesian food such as tempeh gembus, virgin coconut oil (VCO), and dumbo catfish based fish sauce (DCBFS). Tempeh gembus is a traditional food that has unique characteristics especially in its taste because contains amino acids. VCO attracts consumers because of its health aspect. Its raw materials are available in Indonesia. DCBS is a product of fermented fish with salt that has a distinctive taste and is produced in Indonesia. This study aimed to analyze the effect of bromelain on local Indonesian food and its applications. The result showed that the use of bromelain in local Indonesian food could improve the quality and nutritional value of local food. Bromelain can be used in local food like tempeh gembus, virgin coconut oil, and fish sauce from dumbo catfish. The use of bromelain in tempeh gembus could increase both of the water-soluble nitrogen level and the $\mathrm{pH}$ value. However, the addition of bromelain in the production of virgin coconut oil and fish sauce from dumbo catfish could increase the yield of theirs.
\end{abstract}

Keywords : Bromelain, Fish sauce, Local food, Protease, Tempeh gembus, Virgin coconut oil

\section{PENDAHULUAN}

Kemajuan teknologi di industri modern telah mengaplikasikan berbagai macam bentuk enzim di dalam proses produksinya. Hal tersebut diperkuat dengan meningkatnya kesadaran akan efek terhadap lingkungan dari dampak industrialisasi secara kimia (Arshad et al., 2014). Secara umum, berdasarkan reaksinya enzim terbagi menjadi 6 kategori, yaitu: oksidoreduktase, transferase, hidrolase, liase, ligase, dan isomerase (Blanco dan Blanco, 2017). Protease, yang merupakan jenis enzim dari hidrolase, cukup mendominasi pangsa pasar dunia yaitu sekitar $60 \%$ dari total golongan enzim lainnya di mana produsen utama dari protease tersebut adalah Novo Industries, Gist-Brocades, Genencor International, dan Miles Laboratories (Feijoosiota dan Villa, 2011). Bromelin merupakan salah satu protease yang memiliki potensi cukup besar dalam pengaplikasian di bidang industri pangan.

Bromelin (EC 3.4.22.32) merupakan salah satu jenis protease yang biasanya diperoleh dari berbagai bagian tanaman nanas (Ananas comosus) (Pavan et al., 2012). Aktivitas bromelin dipengaruhi oleh berbagai macam faktor, seperti: sumber enzim, jenis substrat, inhibitor, $\mathrm{pH}$, dan suhu. Bromelin yang diperoleh dari daging buah nanas matang cenderung memiliki nilai aktivitas yang lebih tinggi dibandingkan dengan buah nanas mentah dengan kondisi optimum pada $\mathrm{pH}$ 6,5 dan suhu $50^{\circ} \mathrm{C}$ (Sree et al., 2012). Adanya inhibitor berupa ion logam $\mathrm{Fe}^{3+}$ dan $\mathrm{Cu}^{2+}$ mampu menurunkan aktivitas bromelin secara signifikan (Liang et al., 2012). Bromelin dapat diimobilisasi menggunakan matriks yang terbuat dari kitosan dan karagenan untuk menjaga kestabilannya (Sebayang, 2006).

Dalam industri pangan, bromelin dapat diaplikasikan pada baking industry untuk menghasilkan adonan yang lebih mengembang dan produksi tepung hipoalergenik (Kong et al. 2007; Watanabe et al., 2000), agen tenderization dalam proses hidrolisis miofibril pada daging (Hage et al., 2013), agen anti-browning untuk menghambat pencoklatan pada buah dan oksidasi fenol (Chaisakdanungull et al., 2007), dalam pembuatan minuman beralkohol, bromelin digunakan untuk mengatur kestabilan bir dan mengurangi pembentukan busa (Benucci et al., 2011), dan produksi hidrolisat protein dari daging ikan (Elavarasan et al., 2014). Karena aplikasi yang cukup luas di dalam industri pangan, penggunaan bromelin terhadap bahan pangan lokal Indonesia memiliki potensi yang 
besar untuk meningkatkan kualitas mutu dan nilai gizi dari bahan pangan lokal seperti tempe gembus, kecap ikan dan virgin coconut oil (VCO).

\section{Pengaruh Bromelin Terhadap Kualitas Tempe Gembus}

Peran bromelin dalam meningkatkan kualitas tempe gembus dilaporkan pada penelitian Wijaya dan Yunianta (2015) yang bertujuan untuk menentukan konsentrasi dan lama waktu inkubasi dari bromelin yang optimal dalam menghasilkan formula tempe gembus terbaik. Bromelin yang digunakan dalam proses penelitian ini merupakan jenis bromelin komersil. Proses penelitian dimulai dengan pembuatan tempe gembus, yaitu dengan mencampurkan ampas tahu pada masing-masing perlakuan varian konsentrasi bromelin sebanyak 100 ppm, 300 ppm, dan 500 ppm dengan lama inkubasi sesuai dengan masing-masing perlakuan yaitu 2 jam, 4 jam, dan 6 jam. Ampas tahu kemudian dicampur dengan ragi dan difermentasi selama 36 jam hingga menjadi tempe gembus. Tempe gembus yang telah jadi kemudian melalui proses pengujian kadar air, kadar protein terlarut, kadar $\mathrm{N}$-amino, $\mathrm{pH}$, dan uji kesukaan (warna, aroma, tekstur, dan kenampakan). Hasil penelitian menunjukan bahwa perlakuan terbaik berdasarkan parameter kimia dan organoleptik adalah produk tempe gembus dengan penggunaan bromelin sebanyak 500 ppm dan lama inkubasi 6 jam. Parameter kimia yang diperoleh dari perlakuan terbaik adalah kadar air $74,78 \%$, protein terlarut $0,57 \%, \mathrm{~N}$ -

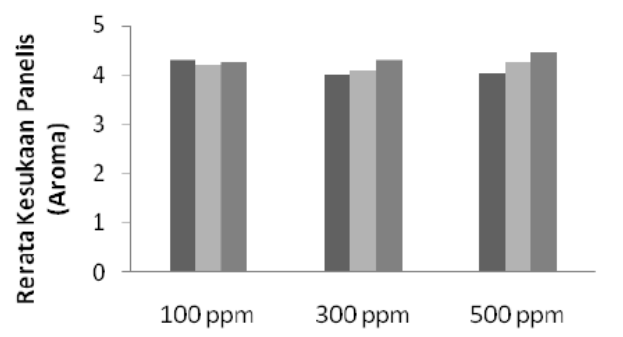

a)

Konsentrasi Enzim Bromelin

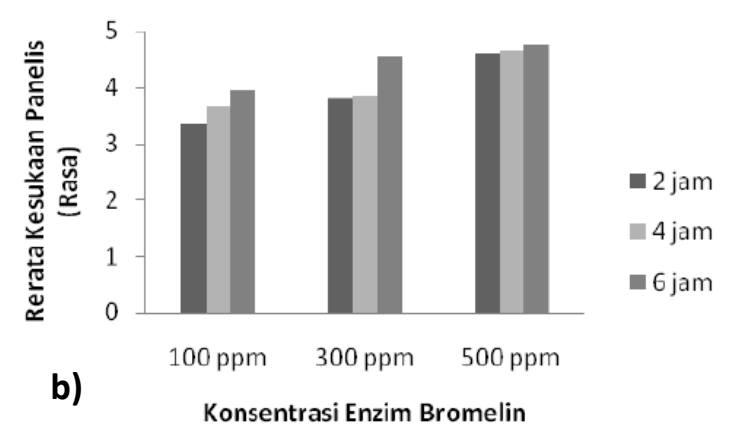

amino $0,13 \%$, dan $\mathrm{pH} 6,66$.

Tingkat kesukaan yang diperoleh dari perlakuan terbaik ditunjukkan pada Gambar 1, yaitu rasa 4,75 (suka), aroma 4,45 (suka), tekstur 3,80 (netral), dan kenampakan 4,50 (suka). Atribut uji rasa memiliki pengaruh yang signifikan, sementara atribut aroma, tekstur, dan kenampakan tidak terdapat pengaruh yang signifikan. Adanya perbedaan signifikan pada atribut rasa disebabkan oleh semakin tinggi konsentrasi bromelin dan waktu inkubasi yang diberikan, maka asam amino hasil hidrolisis enzim akan semakin banyak. Asam glutamat yang dihasilkan selama proses hidrolisis mampu memberikan efek rasa gurih pada tempe gembus.

Air dapat digunakan salah satau sebagai paramater stabilitas dari reaksi enzimatis (Rahman, 2010). Gambar 2 menunjukkan bahwa proses hidrolisis bromelin membutuhkan kandungan air dari dalam bahan, karena sisi aktif enzim saling berikatan dengan substrat melalui ikatan hidrogen (Savitri, 2011). Peningkatan konsentrasi enzim dapat menurunkan kadar air tempe. Menurut Adawiyah et al. (2012), reaksi hidrolisis sangat dipengaruhi oleh keberadaan air di dalam sistem. Penambahan enzim dalam jumlah yang semakin tinggi pada tempe gembus membutuhkan air yang semakin banyak untuk melakukan hidrolisis, sehingga konsentrasi air di pada tempe gembus semakin sedikit (Wijaya dan Yunianta, 2015)

Gambar 2 menunjukkan bahwa semakin tinggi konsentrasi enzim yang ditambahkan dan semakin lama waktu
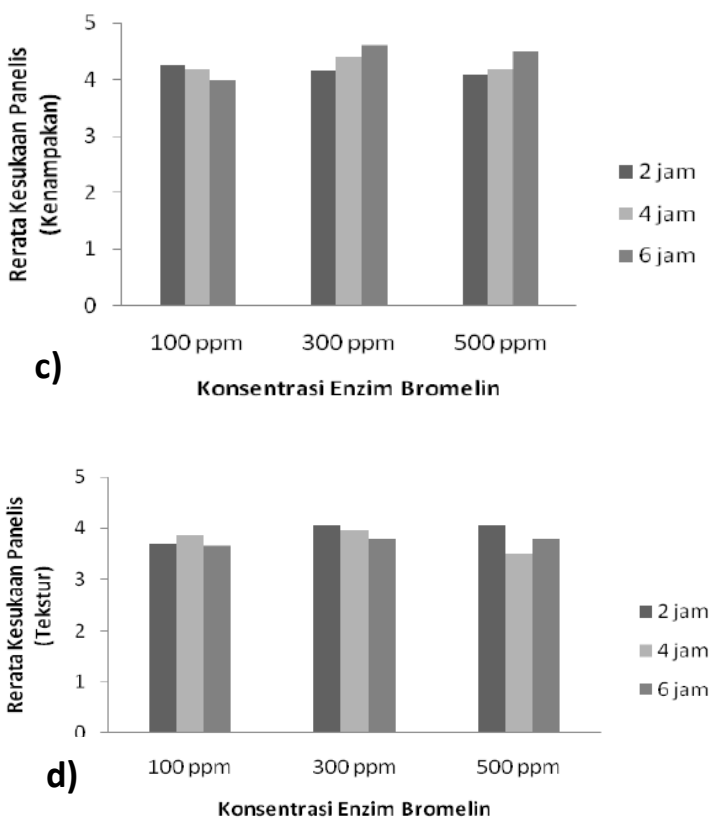

Gambar 1. Rerata Kesukaan Panelis Terhadap Atribut Aroma (a), Rasa (b), Kenampakan (c), dan Tekstur (d) Tempe Gembus (Wijaya dan Yunianta, 2016) 

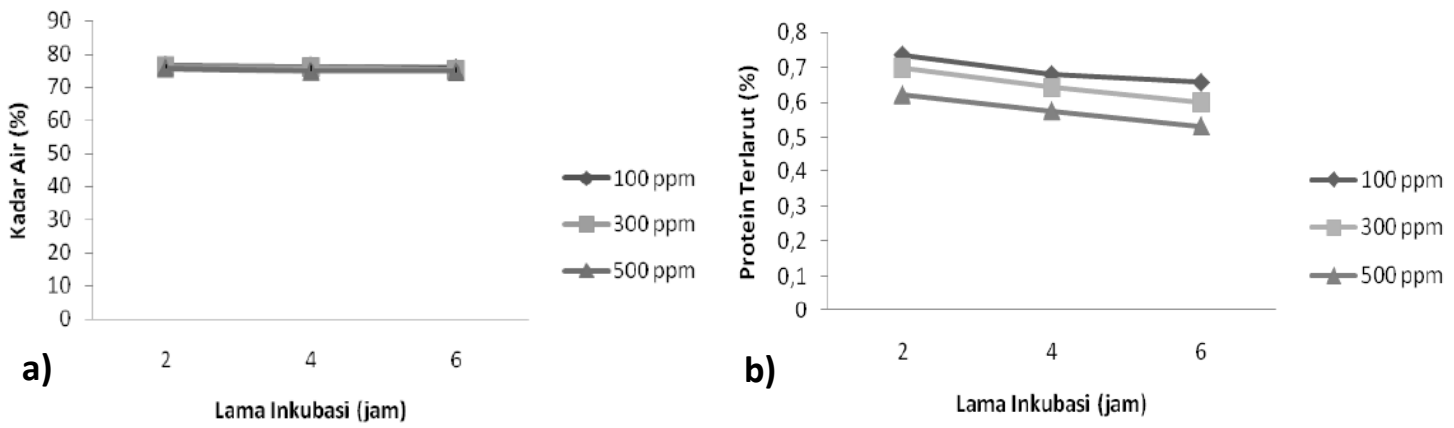

Gambar 2. Pengaruh Konsentrasi Enzim dan Waktu Inkubasi Terhadap Kadar Air (a) dan Protein

Terlarut (b) Tempe Gembus (Wijaya dan Yunianta, 2016)

inkubasi yang dilakukan maka presentase protein terlarut semakin rendah. Menurut Subagio et al. (2002), proses hidrolisis yang terjadi dapat menurunkan berat molekul protein serta meningkatkan jumlah dari gugus polar. Menurut Palupi et al. (2010), hidrolisis protein dapat mengubah sifat protein dari tidak larut menjadi lebih mudah larut, yang kemudian dihidrolisis oleh bromelin dan kapang menjadi asam amino. Hal ini sejalan dengan Susi (2012), yang menyatakan bahwa selama fermentasi tempe, Rhizopus oligosporus menghasilkan enzim proteolitik yang dapat mendagradasi protein kompleks menjadi lebih sederhana. Hal ini menyebabkan jumlah protein terlarut mengalami penurunan.

Gambar 3 menunjukkan pengaruh konsentrasi enzim dan waktu inkubasi terhadap nilai $\mathrm{pH}$ dan total $\mathrm{N}$-amino dari tempe gembus. Semakin tinggi konsentrasi dan lama waktu inkubasi dari bromelin, maka dapat menurunkan kadar protein terlarut dan meningkatkan kadar $\mathrm{N}$-amino dan $\mathrm{pH}$. Menurut Sunarsih (2008), bromelin merupakan hidrolase yang memiliki kemampuan memecah protein menjadi bentuk yang lebih sederhana seperti asam amino (Nurhidayah et al., 2013) dengan bantuan air. Hal ini menyebabkan asam amino yang bersifat hidrofilik, yang memiliki gugus $\mathrm{OH}$ (Florence dan Attwood, 2011) dapat berikatan dengan air sehingga dapat meningkatkan $\mathrm{pH}$ dalam sistem. Hal ini

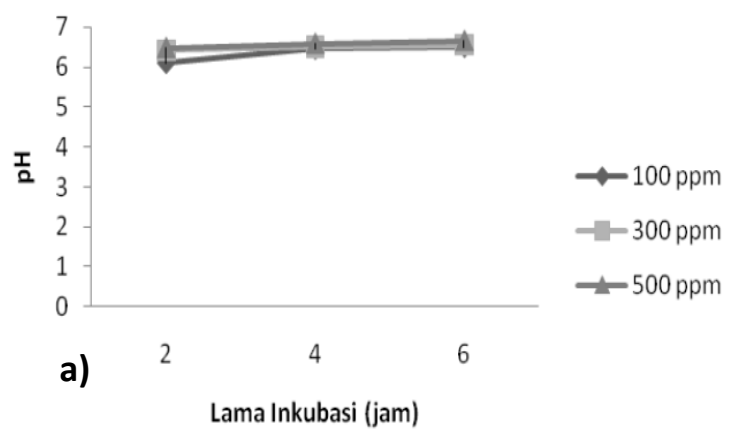

sejalan dengan Utami et al. (2011) yang membuktikan bahwa penambahan ekstrak nanas yang mengandung bromelin dapat meningkatkan $\mathrm{pH}$ daging. Semakin lama waktu inkubasi menyebabkan proses hidrolisis menjadi semakin panjang sehingga mampu meningkatkan kadar nitrogen larut air yang berakibat pada peningkatan $\mathrm{pH}$ (Wijaya dan Yunianta, 2015). Pada penelitian lain menunjukkan bahwa $\mathrm{pH}$ dan suhu optimum dari bromelin berturut-turut yaitu $\mathrm{pH}$ 6,5-8,0 dan $55-60^{\circ} \mathrm{C}$ (Bhattacharya dan Bhattacharyya, .2007).

\section{Pengaruh Bromelin Terhadap Kualitas Kecap Ikan Lele Dumbo}

Aplikasi dan penggunaan protease untuk menghidrolisis daging ikan sebagai substrat sangat banyak dan bervariasi (Himonides et al., 2011). Peran bromelin dalam meningkatkan kualitas kecap ikan lele dumbo dilaporkan pada penelitian terdahulu yang bertujuan untuk mengetahui peranan crude bromelin terhadap kualitas kecap ikan lele dumbo (Dewi et al., 2016). Bromelin yang diekstrak dari buah dan bonggol nanas digunakan sebagai katalisator yang mempercepat proses hidrolisis pada fermentasi kecap ikan lele dumbo. Proses penelitian dimulai dengan mengekstrak crude bromelin dari buah dan bonggol nanas. Setelah itu, daging ikan lele dumbo bersih

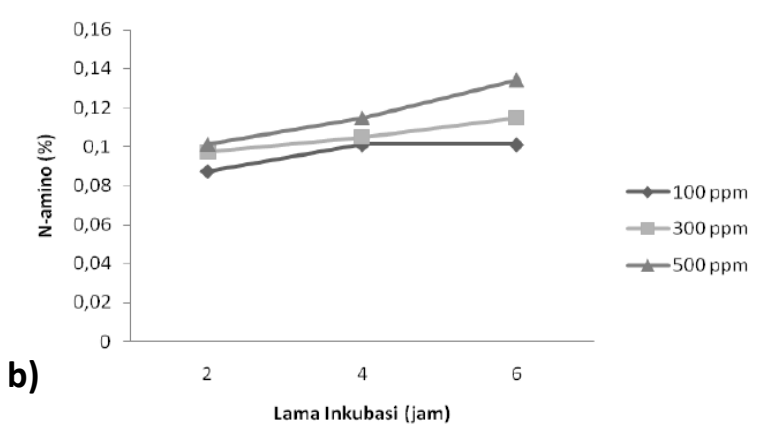

Gambar 3. Pengaruh Konsentrasi Enzim dan Waktu Inkubasi terhadap pH (a) dan N-amino (b) Tempe Gembus (Wijaya dan Yunianta, 2016) 
dicampurkan dengan crude bromelin pada masing - masing varian konsentrasi yang berbeda sebanyak 0\% (kontrol) (P0), 3\% (B3), $6 \%$ (B6), dan $9 \%$ (B9). Seluruh perlakuan difermentasi selama 3 hari pada suhu $50^{\circ} \mathrm{C}$ dan disaring untuk mendapatkan cairan hidrolisatnya. Cairan hidrolisat dipanaskan selama 20 menit pada suhu $80-100^{\circ} \mathrm{C}$ untuk menjadi kecap ikan lele yang selanjutnya dilakukan uji organoleptik (aroma, rasa, tekstur, warna) dan analisis proksimat. Hasil penelitian menunjukan bahwa crude bromelin pada konsentrasi yang berbeda berpengaruh terhadap kualitas kecap ikan lele dumbo yang dihasilkan. Konsentrasi penggunaan bromelin terbaik terhadap kualitas kecap ikan lele dumbo yaitu konsentrasi 9\% karena menghasilkan volume hidrolisat, kadar protein, kadar lemak, dan mutu sensoris paling tinggi yaitu masing-masing sebesar 99,67 ml, $77,86 \%, 6,81 \%$ dan 5,89 yang dapat dilihat pada Tabel 1. Adapun kandungan protein dari tersebut berbeda dengan yang dilaporkan pada penelitian lain yang mengkaji kandungan protein kecap ikan yang dibuat dari limbah surimi yaitu sekitar 11,14-15,33 g/L (Sangjindavong et al., 2009).
2011). Oleh karena itu, karakteristik organoleptik dapat berpengaruh karena adanya hidrolisis protein yang diakibatkan protease, dalam hal ini bromelin.

Berdasarkan Tabel 2 mengenai uji organoleptik kecap ikan, konsentrasi 9\% bromelin memberikan penilaian tertinggi pada atribut warna, tekstur, dan aroma sementara memberikan penilaian terendah pada atribut rasa. Tingginya kadar asam amino dan senyawa pembentuk aroma yang dihasilkan pada konsentrasi 9\% enzim bromalein memberikan efek warna pencoklatan (browning), aroma khas nanas, dan tekstur cair yang lebih disukai oleh panelis. Sementara untuk atribut rasa, lebih tingginya kandungan asam amino dan lemak membuat rasa menjadi kurang enak berdasarkan penilaian panelis (Dewi et al., 2016). Bromelin juga dapat digunakan pada beberapa macam produk berbasis komoditas perikanan lainnya. Wijayanti et al. (2016) telah melakukan penelitian dengan membuat hidrolisat protein ikan bandeng pada varian konsentrasi bromelin yang berbeda. Hasil menunjukkan konsentrasi bromelin memiliki pengaruh yang signifikan terhadap nilai kadar protein, lemak,

Tabel 1. Perbandingan Rerata Paramater (Volume, Kadar Protein, Lemak, dan Air) Kecap Ikan pada Berbagai Perlakuan

\begin{tabular}{clcccc}
\hline \multirow{2}{*}{ No } & \multicolumn{1}{c}{ Parameter } & \multicolumn{3}{c}{ Perlakuan } \\
\cline { 2 - 5 } & & $\mathbf{0 \%}$ & $\mathbf{3 \%}$ & $\mathbf{6 \%}$ & $\mathbf{9 \%}$ \\
\hline 1 & Volume (ml) & 0,00 & 91,33 & 97,00 & 99,67 \\
2 & Kadar Protein (\%bk) & & 62,79 & 67,35 & 77,86 \\
3 & Kadar Lemak (\%bk) & & 3,44 & 4,78 & 6,81 \\
4 & Kadar Air (\%) & & 80,96 & 82,02 & 84,11 \\
\hline
\end{tabular}

Sumber: Dewi et al. (2016)

Bromelin dengan konsentrasi tertinggi $(9 \%)$ mampu meningkatkan hasil hidrolisat yang dihasilkan. Bromelin mampu menghidrolisis protein pada kolagen dan serat otot ikan yang dapat meningkatkan kadar air pada volume hidrolisat. Proteolisis pada kolagen dan serat otot ikan oleh bromelin menghasilkan fragmen protein dengan rantai peptida yang lebih pendek dan asam amino sehingga dapat meningkatkan kadar protein terlarut (Dewi et al., 2016). Peningkatan kadar lemak disebabkan oleh pecahnya ikatan protein pada bagian lipoprotein akibat proses hidrolisis oleh bromelin.

Masalah umum yang timbul dari hidrolisis substrat protein yaitu munculnya rasa pahit (Gerelt et al., 2000). Hal ini telah dilaporkan pada beberapa penelitian dan beberapa di antaranya mencoba untuk mengidentifikasi sifat dari rasa pahit dan menghindari pembentukannya, menghilangkan, atau secara kimia memanipulasi senyawa mengurangi rasa pahit (Hou et al., air, abu, serat kasar dan rendemen $(P<0,05)$, tetapi tidak berpengaruh secara signifikan pada kadar karbohidrat $(P>0,05)$. Kondisi optimum yang digunakan untuk menghidrolisis daging Ikan bandeng menjadi hidrolisat protein adalah dengan varian konsentrasi bromelin $6 \%$ dan lama waktu hidrolisis selama 6 jam (Wijayanti et al., 2016).

\section{Aplikasi Bromelin Pada Pembuatan Virgin Coconut Oil}

Virgin coconut oil (VCO) diekstraksi dari kernel daging kelapa segar dan matang melalui berbagai metode. Tidak ada prasyarat pemrosesan secara spesifik yang ditetapkan dalam memproduksi VCO (Marina et al., 2009a). Beberapa metode yang digunakan untuk memproduksi VCO telah dilakukan, salah satunya menggunakan metode basah, di 
Jurnal Agroteknologi, Vol. 10 No. 1, Agustus $2019: 33-40$

Tabel 2. Perbandingan Paramater Organoleptik (Warna, Tekstur, Rasa, dan Aroma) Kecap Ikan pada Berbagai Perlakuan

\begin{tabular}{clccc}
\hline \multirow{2}{*}{ No } & Parameter & \multicolumn{3}{c}{ Perlakuan } \\
\cline { 2 - 5 } & & $\mathbf{3 \%}$ & $\mathbf{6 \%}$ & $\mathbf{9 \%}$ \\
\hline 1 & Warna & 3,56 & 4,47 & 5,21 \\
2 & Tekstur & 5,99 & 6,49 & 8,07 \\
3 & Rasa & 5,24 & 4,92 & 4,36 \\
4 & Aroma & 4,65 & 4,68 & 5,91 \\
\hline
\end{tabular}

Sumber: Dewi et al. (2016)

mana VCO juga dapat dihasilkan melalui proses enzimatis dan juga fermentasi (Raghavendra dan Raghavarao, 2010). Selain itu, pemanfaatan bromelin dalam pembuatan VCO dilaporkan juga oleh Silaban et al. (2010) yang bertujuan untuk mengetahui pengaruh penambahan bromelin dari nanas pada santan terhadap kualitas VCO yang dibuat dengan metode fermentasi. Bromelin yang digunakan merupakan enzim kasar yang didapatkan dari bagian bonggol nanas yang dihancurkan dan disaring. Penambahan bromelin berfungsi untuk memecah emulgator antara fase air dan minyak pada santan. Penelitian dimulai dengan proses ekstraksi bromelin dari nanas untuk mendapatkan crude bromelin dan persiapan ragi Rhizopus oligosporus. Ragi Rhizopus oligosporus dan ekstrak nanas dicampurkan kedalam $100 \mathrm{ml}$ santan dalam 4 gelas yang berbeda dengan konsentrasi ekstrak nanas dan ragi masing-masing $(0,5 \mathrm{~g}$ : $6 \%) ;(0,5 \mathrm{~g}: 8 \%):(0,5 \mathrm{~g}: 10 \%) ;(0,5 \mathrm{~g}$ : 12\%). Larutan blanko dibuat tanpa penambahan ekstrak nanas dan ragi tempe. Setelah proses pencampuran, proses fermentasi dilakukan selama 24 jam pada kondisi gelap untuk mendapakan VCO. VCO yang diperoleh kemudian dilakukan proses pengujian kadar air, kadar asam lemak bebas, dan bilangan iodin untuk menentukan kualitas dari VCO (Silaban et al., 2010).

Dari hasil penelitian didapatkan bahwa hasil VCO tanpa penambahan ragi dan ekstrak nanas memiliki jumlah yang lebih sedikit dibandingkan dengan penambahan ragi dan ekstrak nanas. Hal tersebut disebabkan adanya protease berupa bromelin pada nanas yang ditambahkan ke dalam santan. Bromelin mendegradasi protein yang memerangkap minyak sehingga minyak dapat keluar dari gumpalan protein. Berdasarkan Gambar $4 a$ mengenai jumlah rendemen perolehan VCO, jumlah VCO yang dihasilkan semakin meningkat dengan meningkatnya penambahan konsentrasi ekstrak nanas. Pada kombinasi penambahan $0,5 \mathrm{~g}$ ragi dan $12 \mathrm{ml}$ ekstrak nanas, terjadi penurunan jumlah VCO yang disebabkan oleh kondisi enzim yang telah mencapai titik jenuh sehingga tidak dapat bekerja dengan optimal. Jumlah VCO terbanyak dihasilkan pada penambahan 0,5 gram ragi dan $10 \mathrm{ml}$ ekstrak nanas sebesar $30,45 \mathrm{ml} / 100 \mathrm{ml}$ santan. Rendemen VCO yang dihasilkan dari penelitian lebih tinggi dibandingkan Anwar dan Salma (2016), yaitu $26,99 \%$. Adapun terkait jumlah protein yang dihasilkan dalam pembuatan VCO dengan metode selain enzimatis seperti cara basah yaitu 45,6\% (Onsaard et al., 2005) dan pengasaman yaitu 16,2\% (Susanto, 2012).

Berdasarkan Gambar 4b mengenai kadar air VCO, pengujian kadar air didapatkan bahwa semakin banyak ekstrak nanas yang ditambahkan, maka semakin tinggi kadar air yang ada pada VCO. Hal ini disebabkan oleh ekstrak nanas memiliki kandungan air yang cukup tinggi sehingga dapat meningkatkan kadar air dari VCO (Silaban et al., 2010). Pada penelitian lain dilaporkan bahwa fermentasi dengan 200 ppm bromelin dan inokulasi $S$. cerevisiae dapat menghasilkan minyak kelapa dengan kualitas terbaik dan mengandung MCFA sesuai dengan standar APCC (Salahudin dan Supriyatna, 2014).

Asam lemak bebas (ALB) adalah ukuran $\mathrm{mg}$ potasium hidroksida yang diperlukan untuk menetralkan asam lemak bebas yang ada dalam $1 \mathrm{~g}$ lemak (Mansor et al., 2012). Berdasarkan Gambar 4c mengenai kadar asam lemak bebas pada VCO, pengujian asam lemak bebas didapatkan kandungan asam lemak bebas berada di antara 0,072 0,19 dimana angka tersebut relatif rendah. ALB yang terkandung dalam VCO sekitar 0,29 $-0,46 \mathrm{mg} \mathrm{KOH} / 1 \mathrm{~g}$ (Marina et al., 2009b). ALB terbentuk dari hidrolisis ester oleh lipase atau uap air yang berpengaruh terhadap rasa dan aroma pada lemak. Semakin lama waktu yang dibutuhkan untuk mengeringkan daging sebelum ekstraksi minyak pada gilirannya, dapat menyebabkan lebih banyak waktu untuk mengalami ketengikan yang dapat terjadi, yang dapat meningkatkan ALB ketika trigliserida dipecah menjadi gliserol dan asam lemak (Osawaa et al., 2007).

Bilangan iodin memiliki pengaruh pada parameter kualitas keseluruhan dari VCO, seperti umur simpan, kenampakan serta rasa dan bau (Mansor et al., 2012). Berdasarkan Gambar 4d mengenai kadar bilangan ionin 
VCO, pengujian bilangan iodin didapatkan bilangan iodin berkisar 7-9 iod/100 gr minyak. Dari hasil penelitian dapat disimpulkan bahwa penambahan ekstrak nanas pada santan dapat menghasilkan VCO lebih banyak dari tanpa penambahan ekstrak nanas.

VCO dengan penambahan ekstrak nanas juga memiliki kualitas yang cukup baik (Silaban et al., 2010). Jika dibandingkan dengan metode lain, penggunaan enzim dapat menghasilkan bilangan iodin yang lebih tinggi (Mansor et al., 2012).

\section{KESIMPULAN DAN SARAN}

\begin{abstract}
Berdasarkan kajian yang telah dilakukan, dapat disimpulkan bahwa penggunaan bromelin 500 ppm dengan lama waktu inkubasi selama 6 jam mampu meningkatkan kandungan asam amino dari tempe gembus. Penggunan crude bromelin dengan jumlah 9\% mampu menghasilkan hidrolisat protein, kadar protein terlarut, dan mutu sensoris maksimum dari kecap ikan lele dumbo. Penambahan bromelin pada pembuatan VCO dan kecap ikan lele dumbo dapat meningkatkan rendemen.
\end{abstract}

\section{Ucapan Terima Kasih}

Ucapan terima kasih diberikan kepada Lembaga Penelitian dan Pengabdian Masyarakat (LPPM) Surya University atas bimbingan dan konsultasi yang telah diberikan.

\section{DAFTAR PUSTAKA}

Adawiyah, D.R., Soekarto, T.S., Hariyadi, P., 2012. Fat hydrolysis in a food model system: effect of water activity and glass transition. Int. Food Res. J. 19, 737-741.

Anwar, C., Salma, Z., 2016. Perubahan rendemen dan mutu virgin coconut oil (VCO) pada berbagai kecepatan putar dan lama waktu sentrifugasi. J. Teknotan 10, 51-60.

Arshad, I.Z.M., Amid, A., Yusof, F., Jaswir, I., Ahmad, K., Loke, S.P., 2014. Bromelain: an overview of industrial application and purification strategies. Appl. Micriobiology Biotechnol. 98: 7283-7297.

Benucci, I., Liburdi, K., Maria, A., Garzillo, V., Esti, M., 2011. Bromelain from pineapple stem in alcoholic - acidic buffers for wine application. Food Chem. 124, 13491353.

Bhattacharya, R., Bhattacharyya, D., 2007. Preservation of natural stability of fruit "bromelain" from. J. Food Biochem. 33, $1-19$.
Blanco, A., Blanco, G., 2017. Enzymes, Medical Biochemsitry. Academic Press, Cambridge, USA.

Chaisakdanungull, C., Theerakulkait, C., Wrolstad, R.D., 2007. Pineapple Juice and Its Fractions in Enzymatic Browning Inhibition of Banana (Musa (AAA Group) Gros Michel). J. Agric. Food Chem. 55, 4252-4257.

Dewi, K., Karnila, R., Loekman, L., 2016. Pengaruh Penambahan Crude Enzim Bromelin Berbeda Terhadap Kualitas Kecap Ikan Lele Dumbo (Clarias gariepinus). Universitas Riau.

Elavarasan, K., Kumar, V.N., Shamasundar, B.A., 2014. Antioxidant and Functional Properties of Fish Protein Hydrolysates from Fresh Water Carp (Catla catla) as Influenced by the Nature of Enzyme. J. Food Process. Preserv. 38, 1207-1214.

Feijoo-siota, L., Villa, T.G., 2011. Native and Biotechnologically Engineered Plant Proteases with Industrial Applications. Food Bioprocess Technol. 4, 1066-1088.

Florence, A., Attwood, D., 2011. Peptides, Proteins and Other Biopharmaceuticals, in: Physicochemical Principles of Pharmacy. Pharmaceutical Press Publishing, London, hal. 451-476.

Gerelt, B., Ikeuchi, Y., Suzuki, A., 2000. Meat Tenderization by Proteolytic Enzymes After Osmotic Dehydration. Meat Sci. 56, 311-318.

Hage, D.S., Anguizola, J.A., Bi, C., Li, R., Matsuda, R., Pfaunmiller, E., Vargas, J., Zheng, X., 2013. Pharmaceutical and biomedical applications of affinity chromatography: recent trends and developments. J. Pharm. Biomed. Anal. 69, 93-105.

Himonides, A.T., Taylor, A.K.D., Morris, A.J., 2011. A Study of the Enzymatic Hydrolysis of Fish Frames Using Model Systems. Food Nutr. Sci. 2, 575-585.

Hou, H., Li, B., Zhao, X., Zhang, Z., Li, P., 2011. Optimization of enzymatic hydrolysis of Alaska pollock frame for preparing protein hydrolysates with lowbitterness. LWT - Food Sci. Technol. 44, 421-428.

Kong, X., Zhou, H., Qian, H., 2007. Enzymatic hydrolysis of wheat gluten by proteases and properties of the resulting hydrolysates. Food Chem. 102, 759-763.

Liang, H., Li, M., Shi, M., Liao, A., Wu, R., 2012. Study on the Stability of Fruit Bromelain. Adv. Mater. Res. 421, 19-22. https://doi.org/10.4028/www.scientific.net/ AMR.421.19

Mansor, T., Che Man, Y., Shuhaimi, M., Abdul, 
A.M.J., $\quad \mathrm{Ku}, \quad$ N.F.K.M., 2012. Physicochemical properties of virgin coconut oil extracted from different processing methods 19, 837-845.

Marina, A.M., Che Man, Y.B., Amin, I., 2009a. Virgin coconut oil: emerging functional food oil. Trends Food Sci. Technol. 20, 481-487.

Marina, A.M., Che Man, Y.B., Nazimah, A.H., Amin, I., 2009b. Chemical Properties of Virgin Coconut Oil. J. Am. Oil Chem. Soc. 86, 301-307.

Nurhidayah, N., Masriany, M., Mashuri, M., 2013. Isolasi dan Pengukuran Aktivitas Enzim Bromelin dari Ekstrak Kasar Batang Nanas (Ananas comosus) Berdasarkan Variasi pH. BioGenesis 1, 116-122.

Onsaard, E., Vittayanont, M., Srigam, S., Mc Clement, D., 2005. Properties and stability of oil in water emulsions stabilized by coconut skim milk protein. J. Agric. Food Chem. 53, 5747-5753.

Osawaa, C.C., Goncalvesa, L.A.G., Ragazzib, S., 2007. Correlation between free fatty acids of vegetable oils evaluated by rapid tests and by the official method. J. Food Compos. Anal. 20, 523-528.

Palupi, N.W., Windrati, W.S., Tamtarini, T., 2010. The Effect of Enzymatic Hydrolysis on the Properties of Protein Hydrolysate from Paddy Mushroom. Makara, Teknol. 14, 73-76.

Pavan, R., Jain, S., Shraddha, S., Kumar, A., 2012. Properties and therapeutic application of bromelain: A review. Biotechnol. Res. Int. 976203, 1-6.

Raghavendra, S.N., Raghavarao, K.S.M.S., 2010. Effect of different treatments for the destabilization of coconut milk emulsion. J. Food Eng. 97, 341-347.

Rahman, M.S., 2010. Food stability determination by macro-micro regio concept in the state diagram and by defining a critical temperature. J. Food Eng. 99, 402-416.

Salahudin, F., Supriyatna, N., 2014. Ekstraksi Minyak Kelapa secara Fermentasi untuk Mempertahankan Mutu Asam Lemak Rantai Sedang. Biopropal Ind. 5, 23-28.

Sangjindavong, M., Mookdasanit, J., Wilaipun, P., Chuapoehuk, P., Akkanvanitch, C., 2009. Using Pineapple to Produce Fish Sauce from Surimi Waste. Kasetsart J. (Natural Sci. 43, 791-795.

Savitri, R., 2011. Aplikasi Proses Hidrolisis Enzimatis dan Fermentasi dalam Pengolahan Condiment Kupang Putih (Corbula faba H.). Institut Pertanian Bogor.
Sebayang, F., 2006. Pengujian stabilitas enzim bromelin yang diisolasi dari bonggol nanas serta imobilisasi menggunakan kappa karagenan. J. Sains Kim. 10, $20-$ 26.

Silaban, R., Manullang, R.S., Hutapea, V., 2010. Pembuatan Virgin Coconut Oil (VCO) Melalui Kombinasi Teknik Fermentasi dan Enzimatis Menggunakan Ekstrak Nenas. Universitas Negeri Medan.

Sree, P.P.S., Jayakumar, K., Mathai, V., Chintu, S., Sarath, B.K., 2012. Immobilization and Kinetic Studies of Bromelain: A Plant Cysteine Protease From Pineapple (Ananas comosus) Plant Parts. Int. J. Med. Heal. Sci. 1, 10-16.

Subagio, A., Hartanti, S., Windrati, W., Unus, U., Fauzi, M., Herry, B., 2002. Kajian Sifat Fisikokimia dan Organoleptik Hidrolisat Tempe Hasil Hidrolisis Protease. J. Teknol dan Ind. Pangan 13, 204-210.

Sunarsih, L., 2008. Uji Efektivitas Ekstrak Buah Nanas (Ananas comosus L. Merr) Muda Varietas Queen Terhadap Mortalitas Cacing Parasit (Ascaridia galli) Secara In Vitro. Universitas Muhammadiyah Malang.

Susanto, T., 2012. Kajian metode pengasaman dalam proses produksi minyak kelapa ditinjau dari mutu produk dan komposisi asam amino blondo. J. Din. Penelit. Ind. 23, 124-130.

Susi, S., 2012. Komposisi Kimia dan Asam Amino pada Tempe Kacang Nagara (Vigna unguiculata ssp. cylindrica). Agroscientiae 19, 28 - 36.

Utami, D.P., Pudjomartatmo, P., Nuhriawangsa, A.M.P., 2011. Manfaat Bromelin dari Ekstrak Buah Nanas (Ananas comosus L. Merr) dan Waktu Pemasakan untuk Meningkatkan Kualitas Daging Itik Afkir. Sains Peternak. 9, 8287.

Watanabe, M., Watanabe, J., Sonoyama, K., Tanabe, S., 2000. Novel method for producing hypoallergenic wheat flour by enzymatic fragmentation of the constituent allergens and its application to food processing. Biosci. Bitechnology, Biochem. 64, 2663-2667.

Wijaya, J.C., Yunianta, Y., 2015. Pengaruh Penambahan Enzim Bromelin Terhadap Sifat Kimia dan Organoleptik Tempe Gembus (Kajian Konsentrasi dan Lama Inkubasi dengan Enzim). J. Pangan dan Agroindustri 3, 96-106.

Wijayanti, I., Romadhon, R., Rianinsih, L., 2016. Karakteristik Hidrolisat Ikan 
Bandeng (Chanos chanos Forsk) dengan

Konsentrasi Enzim Bromelin yang

Berbeda. J. Saintek Perikan. 11, 129-

133. 